\title{
Grundtvig, angelsakserne og Sidste Digt
}

\section{Af Flemming Lundgreen-Nielsen}

Forsøgene på at forstå og tolke Grundtvigs Sidste Digt, »Gammel nok jeg nu er blevet «, er siden 1993 blevet fornyet på både overraskende og frugtbar vis ved sammenligning med den angelsaksiske kristelige digtning fra den tidlige middelalder, som Grundtvig kom til at interessere sig stærkt for, så snart han havde fået øjnene op for den. Både digtets helhed og visse detaljer kan nu indplaceres i denne sammenhæng, skønt ikke alle iagttagelser afledt fra angelsakserne er lige overbevisende. En drøftelse kan fortsætte. Teksten er jo i sig selv, med William Michelsens ord i Grundtvig-Studier 1995, »et inspireret digt. For Grundtvig bestod kunsten nemlig $\mathrm{i}$ at gengive inspirationen så sandt som muligt« (s. 106).

At det angelsaksiske er vigtigt i Grundtvigs tankeverden, har han selv erklæret allerede i 1815, da han læste sig igennem det nyudgivne Beowulf-kvad. Det seneste forskningsresultat på feltet er Ole Vinds vurdering i disputatsen Grundtvigs historiefilosofi, 1999, at kvadet for Grundtvig blev det missing link, som kædede Danmarks og Nordens oldtid til den universalhistoriske udviklings hovedstrøm fra Babel, Hellas og Rom - uden om Tyskland, før Luther (s. 172-181).

Grundtvigs aktive arbejde med angelsaksisk forløber i bølger. Den første udgøres af indlæringen af sproget og studier i Beowulf-kvadet 1815-1820, med oversættelsen eller rettere gendigtningen fra sidstnævnte år som hovedresultatet. Næste bølge er beskæftigelsen med den $\emptyset$ vrige angelsaksiske digtning i Englandssomrene 1829-1831. Tredie bølge kommer med en udgave, oversættelse og efterklang af Phoenixkvadet i 1840, fulgt 1841 af en kyndigt overskuende artikel i tidsskriftet Brage og Idun om Beowulf-udgaver og -forskning. Fjerde bølge består af en tekstkritisk udgave, Beowulfes Beorh, 1861, samt en 2. udgave i 1865 af fordanskningen fra 1820 . Femte, sidste og mindste bølgeslag er Fr. Hammerichs mundtlige gennemgang for den dårligt seende Grundtvig af et lille engelsk skrift om et angelsaksisk digt, foretaget på opfordring tre dage før hans $d \varnothing d$.

En håndfuld danske forskere har siden Fr. Hammerichs De episkkristelige oldkvad hos de gotiske folk, 1873, og F. Rønnings afhandling i Historisk Månedsskrift, IV-V, 1885, beskæftiget sig med Grundtvig og det angelsaksiske. I 1993 har den britiske forsker S.A.J. Bradley i 
Heritage and Prophecy. Grundtvig and the English-Speaking World peget på et hidtil mindre udforsket område: Grundtvigs »interactive and creative response« på det angelsaksiske kristeligt-poetiske univers. Bradley tager udgangspunkt i en stilistisk karakteristik af Grundtvig ved Århus-forskeren Niels Lyhne Jensen (i en Grundtvig-antologi på engelsk fra 1984). Den går ud på, at Grundtvig gerne arbejder med antitetisk opstillede grundmodsætninger (liv-død, dag-nat, etc.) og ofte omtaler lys- og strålefænomener; hans sprog er udpræget substantivisk, endda tit ved sammensatte ord, og han har en skarp opfattelse af ordenes oprindelige betydning (deres rod), hvad der afføder talrige ordspil. Disse træk finder Bradley igen i den gamle angelsaksiske poesi og forstår derfor Grundtvigs glæde ved den - han fornemmer vist, at Grundtvig hos angelsakserne oplever en art genkendelse til bestyrkelse af sin definition af »nordisk « som »nordeuropæisk «, altså med det historiske England regnet til Norden. Et par eksempler fra Exeter-bogens Kristus-digte, som Grundtvig afskrev i 1830, og som gengives sammen med en moderne engelsk oversættelse, ledsages af den oplysning fra Bradley, at mange af de typiske substantiviske sammensætninger er understreget i Grundtvigs manuskript, $\mathrm{fx}$ »sund-hengestum «, dvs. havheste = skibe. Bradley sammenfatter forsigtigt, at disse ord »interesserede« Grundtvig.

Hertil kan en dansk litteraturhistoriker bemærke, at Niels Lyhne Jensens portræt af sprogkunstneren Grundtvig også indeholder hovedtræk, som passer på en af Grundtvigs yndlingsforfattere, barokdigteren Thomas Kingo, - hvis salmer ifølge Nordens Mythologi, 1832, er »ikke blot det Syttende Aarhundredes største Vidunder, men et saa sjeldent i hele Menneske-Historien, at det kun lader sig forklare af Nornens underfulde Viisdom«, en fornyelse, som Cædmon vel prøvede på tusinde år før, men uden held, fordi han savnede den sangbund, som dannekvinden skænkede Kingo (US V, 1907, s. 465 f.).

$\mathrm{Og}$ når Grundtvig i sin angelsaksiske afskrift understreger omskrivningen for skib, skyldes det vel, at han i den genfinder en oldislandsk kenning, han har vidst besked om fra sin pure ungdom (jf. min Det handlende ord, 1980, s. 92, 98, 131 og 121). Hans utrykte nordiske fortælling Ulfhild fra sommeren 1803 har i et indlagt hjemmelavet kvad vendingen »Havenes Heste « om skibe. I et nyt fors $\emptyset$, Ragnhild fra januar-marts 1804, varieres udtrykket til »Bølgens kaade Elge«, hvad der - bortset fra det unorrøne adjektiv - svarer til islandsk »elgr unnar «. Med Jonas Jonæus' udgave på islandsk og latin, Orkneyinga Saga sive Historia Orcadensium, 1780, som kilde fors $\emptyset$ gte Grundtvig i september- 
oktober 1804 at skrive to nordiske fortællinger, Sven Asleyfas $\emptyset n$ og $R \phi g n v a l d$ Jarl. Udkast til begge er bevaret, men forblevet utrykte. I den sidstnævnte indlægger Grundtvig kenningen »alfangs mari« (havets hest) i den ved det tilsatte adjektiv ukorrekte form »Havets udmattede Hest «. Et af Grundtvigs tidlige kildeskrifter, B.C. Sandvigs Danske Sange afdet aldste Tidsrum, 1779, har i »Glossarium« (s. 137) to belæg på »Havets Heste « om skibe. Bent Noack har, ligeledes i Heritage and Prophecy, 1993, fremhævet de gamle angelsakseres og Grundtvigs fælles glæde ved brug af faste, næsten homeriske adjektiver for derpå at minde om, at det velkendte grundtvigske udtryk »hvalernes veje« - som han ikke stedfæster - stammer fra »hron-rad «i Beowulf, 1. sang, vers 10. Måske, men allerede i R $\phi$ gnvald-manuskriptet omskriver Grundtvig havet til »Hvalens Huse« svarende til kildens »hvalfrón«, og den 15. juli 1804 noterer han fra E.J. Biörners saga-udgave Nordiska Kämpa Dater, 1737, et udtryk i Alfs Saga: »Havet kaldes hos Skjaldene 'Hin hvide Fiskes salte Sti'«. I den eksperimenterende prosafortælling efter Hervarar Saga ok Heiðreks, »Sværdet Tirfing «, offentliggjort i Idunna i december 1810, gendigter Grundtvig Hervors kvad bl.a. med linjerne: »Jeg nu til Havets / Heste vil gange« (PS I, 1880, s. 471). Det er altså ikke helt enkelt at sætte sikre mærker ved, hvad der hos Grundtvig efter 1815 er angelsaksisk og hvad der er oldislandsk.

Bradley peger videre i sin 1993-afhandling på yderligere slægtskab (»affinities «) mellem Grundtvigs skriftsprog og angelsaksernes, således i prædikenstilen, men er sig bevidst, at Grundtvig var langt fremme i udviklingen af sine stilarter før det første møde med angelsaksisk - hans bl.a. gennem studier af oldislandsk litteratur udviklede poetiske sans blev »deeply « bekræftet af hans bekendtskab med angelsakserne (s. 6465). Bradley opfordrer til en undersøgelse, der i fuldt omfang kan bestemme Grundtvigs endelige gæld til angelsaksisk poesi.

Som et eksempel nævner han Grundtvigs Sidste Digt, „Gammel nok jeg nu er blevet«, der for ham er beslægtet med Cynewulfs selvkarakteristik i epilogen til Elene (i Exeter-bogen). Bradley medgiver, at billedet af livet som en sejlads over et oprørt hav til en frelsende kyst eller havn er fast inventar i middelalderlig litteratur, ud fra Noas ark og Jesu vandring på søen - hvortil han kunne have føjet belæg fra antikken. Men Grundtvigs holdning til det stormfyldte og gruopvækkende hav minder især Bradley om en gruppe angelsaksiske digte, »Vandreren «, »Søfareren«, »Den landflygtiges bøn« og Cynewulfs epilog til »Kristus « II. Endelig medtager han fra Vercelli-bogen apostlen Andreas' rejse til 
havs mod Mermedonia, hvor en ukendt styrmand bringer skibet frelst til land; bagefter forstår Andreas, at det er Kristus selv, der har færget ham over.

Med sikkerhed at ville bestemme kilder og inspiration, når det gælder et så alment billede, er naturligvis halsløs gerning, og Bradley formulerer sig med rette behersket og forsigtigt. De udsigter, den angelsaksiske synsvinkel åbner, må afprøves ud fra kronologi og tekstsammenhæng (internt og eksternt), før noget kan regnes for bevist. Forekomst af de blotte ord gør det ikke alene. Når fx Grundtvig i sin 1814-verdenskrønike skriver, at »Menneskets udvortes Levnet afbilder saaledes hvad der skal være hans indvortes Liv, en Pilegrimsfærd over Verdens vilde Hav« (s. 7), udelukker kronologien den angelsaksiske indflydelse, billedet kunne angive.

Bradley konkluderer med at spørge, om Grundtvig i Sidste Digt lige før sin død i 1872 virkelig skulle have glemt sin engagerede læsning af angelsakserne for i stedet at ty til »classical allusion and reference to operas and arias of the previous century « (s. 70). Det er en henvisning til min korte skitse af digtet i 1983 i Chr. Thodberg og Anders Pontoppidan Thyssen (red.): Grundtvig og Grundtvigianismen i nyt lys (s. 41), som Bradley lidt tidligere (på sin s. 66) har citeret fra den engelske udgave.

Bradleys forskning i Grundtvigs angelsaksiske studier - hans læsning, afskrivning, oversættelse, gendigtning og egen poetiske inspiration - repræsenterer en kærkommen og tiltrængt indsats på et område, næsten ingen nulevende aktive Grundtvig-forskere i Danmark behersker kulturhistorisk eller sprogligt. Den har allerede givet værdifulde resultater til forståelsen af digteren Grundtvig, og mere kan ventes. Bradley har på sin faglige baggrund kunnet udpege træk efter træk til forklaring af Grundtvigs samfølelse - »fellow-feeling " (Heritage and Prophecy, s. 64) - med den angelsaksiske poesi, der for digterens frydefuldt undrende øjne var steget op af Vesterhavet som en ny og dog gammelkendt verden. Alligevel er Bradleys spørgsmål måske, med bagvægt på hans egen fornemmelse af det rimeligste svar, opstillet lidt for selvfølgeligt, når det gælder om at udrede, hvad jeg i 1983 kaldte Sidste Digt for: en overvejende uevangelisk myte. Det er et symptom på en nok utilsigtet glidning i dokumentationen, at Bradley på s. 65 for sit engelske publikum oversætter sjæle-færge-stavnen til »the soul-ship's prow «, selv om engelsk har det præcisere ord »ferry«; engelske leksika betegner ellers ufortøvet Karon som »the ferryman of death «. 
Bradley skelner mellem to lag i Grundtvigs bevidsthed, ét, som angår hans 19. århundredes kontekst, et andet, som gælder hans evne til at indoptage og genopleve ældre tiders poesi, in casu den tidlige middelalders kristne litteratur i England. Bradleys forskning rettes mod det sidste, både mentalitetshistorisk, litterært og filologisk, så han på slutsiderne i sit bidrag smukt og velgennemtænkt kan placere Grundtvig som anglo-saxonist dengang, siden, nu og i en fremtid.

Bradley har utvivlsomt fat i noget rigtigt og spændende ved Sidste Digt uden dog at løse alle udestående problemer. Det er sandt, at de havmetaforer, jeg i 1983 angav som faste vendinger i lyrik af Stub, Brorson, Wessel og Ewald og siden i en lille opsats om ordet »Sjæle-FærgeStavnen « i Grundtvig-Studier 1994 har udfoldet i citater (s. 112-115), stammer fra »the previous century « - det 18. århundrede. Det gør Grundtvig for resten også, og de to sidstnævnte digtere var ifølge private optegnelser yndlingslæsning for den unge Grundtvig i henholdsvis sommeren 1802 og februar 1805 . Til langt over midten af det 19. århundrede var fødselsår i det forrige århundrede ingen selvfølgelig grund til diskvalifikation for forældelse. Da Grundtvig blev født i 1783, var der kun gået fire år siden offentliggørelsen af Ewalds sidste drama Fiskerne, tre år siden dets vellykkede opførelse på Det Kongelige Teater og to år siden digterens død og hæderfulde bisættelse. Ewald var for Grundtvig og hans jævnaldrende den store danske klassiker, i følelsesdybde og sprogkraft langt mere moderne end Holberg. Højromantikerne så ikke Ewald som en gammeldags skribent fra en svunden tid. Oehlenschlägers digt »Gibs-Billedet «i »Langelandsreise «(Poetiske Skrifter, 1805) er karakteristisk. Det beskriver, hvorledes den rejsende unge poet tager en tilrøget gipsfigur for Voltaire, men ved nærmere eftersyn bliver klar over, at det er Ewald: »Da trængte Taaren i mit Øye, / Og Øyet brændte, Hiertet slog «. I den næste strofe erklærer han, at det var Ewald, »Som smilte, naar min Musa smilte, / Som standsed mig naar Aanden hvilte, / Som styrked og som hæved mig«. Ikke underligt, at Oehlenschläger ved sin tiltrædelse som københavnsk universitetsprofessor i æstetik i vinteren 1810-1811 holdt forelæsninger over Ewalds værker med righoldige citater af pragtstederne; Grundtvig fulgte disse foredrag, til han blev hjems $\emptyset$ gt af sit første sindssygeanfald i december 1810. Ewalds romance »Kong Christian stoed ved høien Mast « fra Fiskerne var med D.L. Rogerts melodi en født klassiker, optoges i sangbøger fra og med 1781 og fik forstærket sin position i publikum ved J.L. Heibergs og Fr. Kuhlaus genbrug i festspillet 
Elverh $\phi j, 1828$, til dato det hyppigst opførte danske skuespil. I 1831, halvtredsåret for Ewalds død, havde Det Kongelige Teater sat det heroiske syngespil Balders $D \phi d$ (1775) op og derved atter erindret københavnerne om Ewald, ja, året efter bekostede man endda nykomponeret musik til stykket ved romantikkens bedste komponist, den i dette tilfælde desværre uinspirerede C.E.F. Weyse. I Nordens Mythologi, 1832, citerer Grundtvig kongesangens slutstrofe om havet (US V, 1907, s. 466 f.). Han omtaler også Balder-dramaet og Fiskerne, hvoraf navnlig det sidste interesserer ham, fordi Ewald er den første digter siden vikingetiden, der har set havet som dansk og nordisk ånds vugge, en frugtbar udfordring til folkenes virke- og kamplyst. Tanken om havets udviklende kraft bliver afgørende for kompositionen af Grundtvigs tre bind verdenshistorie 1833-56 med bind I, Oldtiden, samlet om Middelhavet, bind II, Middelalderen, om Østersøen og bind III, Nyårstiden, om Verdenshavet (Atlanten). Det fremgår af katalogen (i Grundtvig-arkivets fasc. 520) over Grundtvigs bibliotek i 1839 (-ca. 1843), at skønt han kun ejede forholdsvis få titler af danske samtidsdigtere, havde han hele to udgaver stående af Ewalds samlede skrifter. Og mange gange, når den modne Grundtvig skriver eller siger ordet »Hav«, føjer han automatisk kongesangens »sortladne « til, endog i prædikener (jf. fx Merete Bøye i Grundtvig-Studier 1998, s. 129 med note 27).

Det kunne ligeledes i tørre fakta demonstreres, hvorledes det 19. århundredes digtere, fx H.C. Andersen, Grundtvig og Kierkegaard, genopdager Stub og Brorson; Wessel havde lige siden sin død tjent som leverand $\varnothing r$ af vittige citater og kom i en gennemillustreret pragtudgave ved P.L. Møller i 1848, den til dato fuldstændigste.

Det er således ikke berettiget, at Bradley diskret antyder det støvede og fjerne hos Ewald og Wessel. De var døde 1781 og 1785 i en alder af kun 37 og 43 år, de udsendtes umiddelbart efter deres bortgang i samlede skrifter (henholdsvis 1780-1791 og 1787), og personlige erindringer om dem var levende i hovedstaden helt op i 1830'rne. Begge var selvfølgelige st $\varnothing$ rrelser i det litterære landskab. De angelsaksiske tekster, hvis indflydelse Bradley vil give første prioritet, er ca. 1000 år ældre. De kendes først af Grundtvig i hans 32. leveår, og trods hans helhjertede fors $\emptyset \mathrm{g}$ på at puste liv i dem fik han aldrig folkelig opbakning til at indlemme dem i dansk historisk tradition. Med al respekt for den angelsaksiske styrts $\varnothing$, som i 1815 ramte Grundtvig, stod han kulturelt betragtet med begge ben på ærkekøbenhavnsk og dansk grund. Hypotesen om den angelsaksiske gennemslagskraft må desuden svækkes 
ved, at Grundtvigs oversættelser af Beowulf og Phoenix er holdt i romantiske ballade-metre eller i folkeviseform. I 1815 var Grundtvigs inventar af lyriske stilarter næsten komplet, så det angelsaksiske betød på et poetisk-teknisk niveau en organisk udvidelse mere end et afgørende nybrud. Grundtvigs fors $\emptyset \mathrm{g}$ på at digte selvstændigt på angelsaksisk skal ikke glemmes, men er og forbliver kuriositeter svarende til hans $\emptyset$ vrige versstumper på andre sprog end dansk.

Hvad angår Bradleys affærdigelse af »classical allusion«, altså en læsning af digtet som en kristeligt forvendt Karonsmyte, kan det naturligvis altid diskuteres, hvor bredt og vagt eller snævert og præcist en omdigtning skal spejle det mulige forbillede. En lignende uvished gælder i øvrigt Bradleys påvisning af ligheder og slægtskab mellem angelsaksernes og Grundtvigs kristelige digtning. Hans referater synes undertiden at demonstrere, at kun helhedsstemning og visse enkelttræk er ens. Således er de angelsaksiske digtes personer pilgrimme eller missionærer på vej til et nyt aktivitetsområde på jorden, mens Grundtvigs sejlads går fra denne verden til himmerig og evigheden. I apostlen Andreas' tilfælde røbes det først ved rejsens lykkelige ende for den bange rejsende, at skibets styrmand er Kristus selv, mens Grundtvigs jeg-fortæller allerede »paa Falde-Rebet«, altså før han stiger om bord, véd, at »Guds Aand « står for roret.

Grundtvigs vers om den uproblematiske rute til dødsriget i Sidste Digts strofe 2: »Nærmest er de Dødes Rige / Nemt det er at stævne did « forekommer mig stadig at give bedst mening som et lån fra græsk mytologi, der også har leveret begrebet til strofe 3 om en færge for sjælene. Er det mon ikke grunden til, at netop disse to vers (og de to følgende med) udelades i Bradleys eksemplificering s. 68 af Grundtvigs uddestillering af angelsaksiske ideer om søen?

Oven på de hektiske studier i angelsaksisk havde Grundtvig imidlertid ikke glemt grækerne, hvad der er tydeligt i forarbejderne til Nordens Mythologi, 1832. I 1833 påbegyndte Grundtvig en oversættelse af Iliaden forfra (PS V, 1883, s. 558-563). I bind I af Haandbog $i$ VerdensHistorien, 1833, har han i lange baner repeteret skrifter fra den græske antik, som det ses af de talrige fodnoter, og til bøgerne Brage-Snak, 390 tryksider, 1844, og Grask og Nordisk Mythologi for Ungdommen, 286 tryksider, 1847 (dvs. december 1846), er der bevaret forarbejder på rundeligt anslået 1600 manuskriptsider, hvoraf mere end halvdelen handler om græske myter. Der er ikke årsag til at antage, at Grundtvig i 1872 skulle være kommet meget langt bort fra græsk mytologi. 
Men selv dette taget $\mathrm{i}$ betragtning er det en definitiv vinding $\mathrm{i}$ Bradleys læsning, at de frygtelige og forstandslammende storme kan belægges i de elegiske angelsaksiske havdigte. Angelsakserne syntes at have opfattet søtrafik ud fra samme opskræmthed og paniske angst, som hersker i Bibelens få scener på eller ved hav og sø. Er det mon, fordi de angelsaksiske forfattere personligt savner fortrolighed med havet, er landfaste boglærde munke med base i deres stenceller? Den lidt yngre vikingetids poesi ser i havet - som Grundtvig også helst gør det - en udfordring, et vidt område at udfolde sig på, vejen til ry og magt. Mindre heroisk formuleret er havet efter en kilde, der i tid ligger tæt på angelsakserne, også skueplads for danskernes hverdagsliv - det drejer sig om et citat af den frankiske hofdigter Ermold Nigellus fra 827, som Grundtvig har indlagt i digtsamlingen Heimdall, 1816: »De Danske boe paa Havet« (digtet »Et Blad af Jyllands Rimkrønike«, str. 138). Forskellen på angelsaksisk og gammelnordisk havdigtning er så tydelig, at det, hvor Grundtvig overgiver sig til angsten for havet, er fristende nok at regne med litterær indflydelse fra angelsakserne. I bed $\varnothing$ mmelsen af den danske flådes indsats 1801-1808, 1848-50 og 1864 lider Grundtvig ikke af vandskræk på matrosernes vegne. Under gentagne henvisninger til slaget på reden og Willemoes ved Sjællands Odde advarer han mod for megen teori og for mange boglige prøver i uddannelsen af danske søkadetter (fx i sit tidsskrift Danskeren, 1851, nr. 16).

For resten bør man ikke overse yderligere en engelsk(sproget) indflydelse på Grundtvigs hav-billeder, nemlig Ossians digte 1760-1765 (jf. stikordregistret i min Det handlende ord, 1980). I et fragment af en nordisk fortælling fra ca. april 1802, Carl M $\phi$ rske, har Grundtvig indlagt et landskab med Ossianske ingredienser: stejle klipper, tårnh $\varnothing j e ~ b ø l g e r$, hul torden, lyn i mørket. Henrich Steffens har ifølge Grundtvig i sine 1803-forelæsninger om Goethe været inde på Ossian, mens Grundtvig ikke selv læser ham før på Egeløkke. Ved sin afsked den 14. januar 1808 med det langelandske læseselskab fik Grundtvig lov til at beholde et af de indkøbte værker og valgte da F.L.v. Stolbergs tyske Ossianoversættelse i tre bind, 1806. I en lidt ældre dagbogsnotits skriver Grundtvig, at han er mere interesseret i Ossians poetiske værd end i den mulige historiske ægthed, hvad han gentager i sin verdenskrønike af 1817, med forbehold for at få teksten at se på engelsk. Men da havde han jo allerede stiftet bekendtskab med en ægtere vare i Beowulf. Er der mon 
nogen litteraturhistorisk forbindelse mellem den angelsaksiske poesi og Macphersons Ossian-digte?

Bent Noacks gennemgang af Sidste Digt i Vartovbogen, 1993 (s. 108-112), fik mig til at skrive en tektkritisk drøftelse af ordet »SjæleFærge-Stavnen« i Grundtvig-Studier 1994 (s. 108-123), hvor jeg søgte en så definitiv afgørelse på dette tydningsproblem som muligt. Resultatet blev, at det midterste led i sammensætningen ikke kan læses » Øje« eller » og at det midterste bogstavs bue til venstre under linjen ikke tillader læsningen »Øie« eller »øie«. Med stor sikkerhed kan der læses »ærge«, hvorefter det store forbogstav kan tydes som $» F \ll$, ikke ulig det i strofe 1 's $»$ Falderebet $\ll$.

William Michelsen tilsluttede sig læsningen »Sjæle-Færge-Stavnen «, hvad der gav ham anledning til et lille bidrag i Grundtvig-Studier 1995, »Om tankebilledet i Grundtvigs sidste digt « (s. 102-106). Her afviste han dog tolkningen af teksten som en forvendt Karon-myte, fordi han fandt et andet tankebillede i teksten - den handler om, at dødsriget ikke er den sikre havn for ethvert menneske, og derfor kan båden ikke være Karons og retningen ikke gå mod dødsriget. Det kan han have ret i, men ligger det ikke i begrebet "forvendt «, at ikke blot erstattes færgekarlen Karon med stagen af Helligånden med ror og Bibel-kompas, og den gamle, sorte, rådne pram (jf. Vergils Aneide, VI, v. 298-308) af en mere sødygtig sjælefærge, men også færden skifter destination og går til Himlens havn i stedet for ad Helvede til?

Med en berettiget undren over, at Grundtvig her lader havet betyde døden, mens det ellers hos ham betegner historien eller menneskelivet, fortsætter Michelsen med at understrege, at der er tale om en rejse, som kan ende i dødsriget eller himmelhavnen. Netop de muligheder mener Michelsen er til stede i Grundtvigs "gamle verdensbillede«, som er nordisk-mytologisk: »I den nordiske mytologi forestillede man sig den beboede jord omgivet af et vældigt hav, som adskilte jorden fra dødsriget Hel eller Valhal«. Det »Paradis«, som er nævnt i strofe 3, anskuer Michelsen derfor som »den nordiske mytologis Valhal kristeligt forvendt « (s. 104). Denne fremstilling af nordisk mytologi - som ikke i sig selv danner noget modsigelsesfrit og sammenhængende univers - er næppe holdbar. Kilderne placerer desværre kun Valhal og Hel uklart og uden enighed, og Grundtvigs egne behandlinger er ikke mere oplysende. Den traditionelle videnskabelige autoritet i nordisk mytologi er Jan de Vries' Altgermanische Religionsgeschichte i 2. helt omarbejdede udgave 
fra 1956-1957. Mytologiens verdensbillede behandles i § 579-581, med det resultat, at menneskene forestilles boende midt i verden, i Midgård, oprindeligt var gudernes Asgård placeret $i$ centrum af menneskenes samfund, men senere flytter troen Asgård op i luften, med Valhal og tilst $\varnothing$ dende gudeboliger; uden for den civiliserede verden ligger Udgård med uoverstigelige fjelde, dystre sumpe, uigennemtrængelige skove og en befolkning af jætter og onde ånder. Jan de Vries henfører denne model til en fastlandskultur; hos kystbeboere kan den suppleres med en forestilling om, at alle landene omkredses af et vældigt verdenshav, der yderst ude $\mathrm{i}$ horisonten styrter ned $\mathrm{i}$ en gabende afgrund. Men siden vikingetiden er havet vesterude slet ikke den gru for nordboerne, som det var for den keltiske befolkning i Irland, skriver de Vries. Saxo henlægger dog i sin VIII. bog underverdenen til et uvist sted bag mange dages sejlads i mørke, kulde og storm, »en Langeleds-Fart « hedder det i Grundtvigs fordanskning 1819 af den ufortrødne islænder Thorkild Adelfars to ekspeditioner dertil.

Grundtvig kender samme hovedkilder som de Vries, men har sine yndlingssteder, således Saxos I. bog om Haddings ridt med Odin på Sleipners ryg over det vilde hav. Men når Grundtvig udtaler sig om Valhal, er han meget usikrere i mælet, end Michelsen er i sin identifikation af tankebilledet. Valhal vil Grundtvig i hovedværket Nordens Mythologi, 1832, ikke placere på et bestemt punkt på landkortet - det er en lokalitet i bevidstheden, udtryk for et $\varnothing$ nske om jordisk udødelighed ud fra en følelse af slægternes gang og hemmelige sammenhæng, et ærens tempel og en evighedens forgård: »det laae naturligviis midt iblandt os eller ingensteds « (US V, 1907, s. 584 ff., jf. Grask og Nordisk Mythologi, 1847, s. 231) - hvad der lyder som et ekko af Lotharios morale i Goethes roman om Wilhelm Meisters læreår: »hier, oder nirgend ist Amerika!« (7. Buch, Kap. 3).

Lige så omhyggeligt vag i det geografiske er Grundtvig i sine $\emptyset$ vrige fremstillinger. Det er derfor heller ikke muligt at sandsynliggøre, at Grundtvigs »Paradis« i strofe 3 af Sidste Digt skulle være et kristeligt forvendt Valhal; teksten rummer - mærkeligt nok - intet, som med sikkerhed kan henføres til nordisk mytologi. I myterne kan man ride til Valhal, alene eller i hærfølge, køre med bukkeforspand fra og til Asgård, komme op og ned via en bro, men sejlruter til asernes boliger haves ikke.

Michelsen mener i konsekvens af sin paradis-tolkning, at himmelhavnen så bliver indgangen til det evige liv, hvor gudsbordet venter, og heri kan man ikke være uenig. Udtrykket »som i Eventyret « forstår han 
som ophævelsen af (jordisk) tid, så det er genren, ikke en bestemt tekst, der henvises til. Dertil kan føjes, at det - eventyrgenren tro - sker pludseligt, med pustet af et ord, altså ved en magisk forvandling: »brat, som sagt, saa gjort «. Det er måske også en erindring om Steffens' beskrivelse i den 7. indledningsforelæsning af den svundne urtid, da guderne gik på jorden og ord og handling endnu var ét og det samme.

Videre bestemmer Michelsen netop i kraft af læsningen sjælefærge Sidste Digt som mere end et personligt bortgangskvæde, nemlig et livsanskuelsesdigt gældende hver kristen. Den afviste læseform »Sjæle- $\varnothing$ jeStavn « angav for ham »et personligt skib « (hvad der dog ikke står noget om i teksten), mens en færge er »et stort skib, der rummer mange mennesker«. Ja, kunne man føje til, netop som Karons overfyldte båd. Michelsens iagttagelse kan bekræftes af, at digtet skifter pronomen fra »jeg « (to gange i strofe 1) til »os « (strofe 3) og »vi « (str. 5), men er dette nødvendigvis andet og mere, end at det fra og med strofe 3 er en trøst for den rejsende, at han ikke er alene, at der er et menneskeligt og kristent fællesskab, han også indgår i? Med strofe l's »jeg " (som vel underforstås også i strofe 2) er inspirationspunktet en speciel situation: trætheden ved byrden af de næsten 89 leveår. At Grundtvig i 1872 opfatter sin egen både individuelle og historiske personlighed som et symbol på menneskehedens, Nordens og Danmarks historie og utvunget kan gøre »jeg « til »vi« og omvendt også kan inkludere medkristne i sin egen oplevelse, her af døden, kan på baggrund af hans tidligere poetiske tekster ikke overraske. Det bestyrkes ved indledningsverset til hele digtet, ekkoet af Nornegæsts dødsreplik, som digtets kristelige tolkere plejer at se bort fra. Nornegæst var som sent kristnet hedensk skjald med poetisk-profetisk kraft både et billede på Grundtvigs egen udvikling og på Nordens universalhistoriske ånd. Men Nornegæsts holdning indebærer én ting til: det er frivilligt, han dør som 300-årig, ved at lade det fortryllede lys, han har slæbt med gennem hele livet, tænde og stille brænde ud. Heller ikke Grundtvig gør modstand mod nu at skulle slutte det jordiske liv. Kan det regnes for almengyldigt i det kristne menneskes eksistentielle situation i døden?

Sjælefærgen, som altså er beregnet på mere end én sjæl, vil Michelsen derpå tolke som den kristne kirke. Det giver ham imidlertid nye problemer. Tekstens strofe 1 skulle i hans læsning angive, at Grundtvig i afskeds- og dødsøjeblikket $\mathrm{i}$ henhold til en nordisk-mytologisk tankegang (som ikke står i digtet!) er midt i livet og derfor - hvor han tidligere har kaldt kirken et hus af levende stene - kan se kirken som et 
skib. Jeg læser, at der i ordene »Gammel nok « og de to gange »Nu « markeres en grænse, ikke et midtpunkt. Det store vilde hav kan ikke, som Michelsen refererer, være »tilværelsens «, for så skulle ifølge strofe 2 Grundtvigs (næsten) sidste ord om denne gå ud på, at den er hjemsøgt af så frygtelige storme, at menneskeforstanden står stille derved. Sådan var og er Grundtvigs syn på tilværelsen ikke. Digtet handler om en overgang fra liv gennem død til liv - Michelsen siger »en yderst farefuld færd « (s. 103). At stå »paa Falderebet « betyder en afsked med jordens trygge havn til fordel for et utvivlsomt skrøbeligere, men midlertidigt transportmiddel. Strofe 2 forstår Michelsen som et valg mellem at strande i de dødes rige eller gå under midt på havet (s. 105). Jeg læser »did « og »der« som betegnelser for det samme, dødsriget, mens »her « er havet, dødsprocessen, det grufyldte område, det gælder om at komme igennem. Grundtvig udstyrer de dødes rige med to besnærende positive betegnelser, »Nærmest « og »Nemt«, som dog derefter kvases med den tredje og negative: »Bundløs« dér er undergangen. Bundløse søer og huler er netop i antik tradition indgange til Hades, således Avernersøen hos Vergil (Eneiden, VI, v. 237-242). Udtrykket »at stævne« kan næppe angive nogen stranding, det er tværtom en rutinemæssigt styret fart, måske endda med en færge (som Karons). At man med Helligånden ved roret umuligt kan ende i de dødes rige, siger sig selv, og den af Michelsen nævnte risiko for, at styrmanden kunne »lade sig lokke af dødsrigets kyst« (s. 105), må være udelukket. Det kan kun være en feberfantasi hos den angste passager og lægger op til en helt anden historie, som så må dementere Grundtvigs tryghed ved navigationen $\mathrm{i}$ strofe 1 .

Paradiset i strofe 3 vil Michelsen forbinde til Jakobs drøm om himmelstigen (1. Mosebog, kap. 28), som jeg ikke kan se spor af i teksten. Jakobs udbytte af i drømme at have oplevet stigen til og fra himmelens port er angst, fordi det er forfærdeligt at sove på et helligt sted uden at have vidst det. Grundtvigs oplevelse af paradisets åndelige eksistens overalt, hvor Gud prises og forkyndes, er anderledes positiv. Han kommer først på vegne af den materielle verden, han er ved at forlade, med en indrømmelse: »Vel, paa jordisk Viis at regne / Langt af Led er Paradis«. Det gammelmodige »Langt af Led « minder om den senmiddelalderlige danske version af skolebogen Lucidarius, der er udformet som dialoger mellem en lærer og en elev. Et af emnerne er Paradis' beliggenhed. Læreren fortæller, at Asien ligger østpå, hvor solen står op, og nærmest ved Paradis, allernærmest er India, men til det er det stor- 
ligen ondt at komme, fordi det er omflydt af to store have og i $\varnothing v$ rigt ligger så langt fra alle lande, at det tager et halvt år at nå derover. Læreren meddeler endelig den håbefulde elev, at til Paradis er det umuligt for jorderiges mennesker at komme, fordi det ligger så højt, at det rager op over over alle skyer, og er omgivet af en ildmur, udenom er der høje bjerge og skove, udenom igen grimme kær og moser, fyldt med drager og onde ånder. Grundtvigs vekslende drøftelser af paradisets jordiske adresse i hans verdenshistorier er ikke præcisere.

I Sidste Digt skifter Grundtvig derfor resolut fra den jordiske til den ujordiske, altså kristne, pejling af Paradis: »Er os nært dog allevegne «. Den omhyggelige sætningsbygning med »Paradis« som på én gang udtrykkeligt og underforstået subjekt for det gentagne verbum »er« angiver, at det oprindelige, tabte eller aflukkede jordiske paradis er tilgængeligt $\mathrm{i}$ ånden, hvor som helst og når som helst sand kristendom forkyndes. Sejladsen i dødstimen over havet er frygtelig og uomgængelig, men selv undervejs er det muligt at styrke sig ved åndelig fremkaldelse og fastholdelse af det Paradis, der ligger forude som rejsens mål, bag Himmelhavnen. Det er det, der trods alt letter rejsen og får jeg'et til at se bort fra den kortere og hurtigere tur til de dødes rige. Her forvendes Karonsbilledet effektivt, sejladsen er til frelse, ikke til fortabelse i skyggernes rige.

I fortsættelse navnlig af S.A.J. Bradleys undersøgelser af det angelsaksiske hos Grundtvig har Merete Bøye i Grundtvig-Studier 1998 været inde på Sidste Digt $\mathrm{i}$ et bidrag betitlet »Hallen og havet som eskatologiske modsætninger - $\mathrm{i}$ den angelsaksiske poesi og hos Grundtvig«. Ud fra Henning Høirups redegørelse i 1954 for Grundtvigs dualisme mellem de eksistentielle modsætninger liv og død ser Bøye i den angelsaksiske digtning to udtryk for det samme - nemlig hallen, som Beowulf kæmper i og for, og havet, som han betvinger. Et fornyet udgangspunkt bliver et citat i Andreas Haarders bog Det episke liv, 1979, af et afsnit fra angelsakseren Bedas latinske kirkehistorie (afsluttet 731). Det drejer sig om en parabel, hvor det korte menneskeliv skildres som en flugten af en spurv ved vintertide gennem en oplyst og varm hal fra den ene dør til den anden, fuglen kommer fra det ubekendte mørke udenfor og vender tilbage til det. Dette billede videreudbygger Bøye ved et udsagn af Andreas Haarder - med kraftig resonans af Vilhelm Grønbechs forkyndende forskning i hedensk-nordisk mentalitet hvorefter hallen hos angelsakserne er livscenter for menneskeligt fællesskab, festritualer og skjaldekunst. Herfra koder hun så, igen via 
Høirup, tilbage til Grundtvigs tanker om de kristnes fællesskab, festmåltid og dyrkelse af ordet - hvad der let lader sig belægge med et par salmecitater fra ham. Tesen bliver herefter, at Grundtvig svarende til angelsaksisk poesi har taget hallen til sig som billede på kirken og paradiset. Omvendt bliver havet ud fra en række angelsaksiske kilder samt Høirups definition af døden bestemt som ensomhed, opløsning af fællesskab, tilintetgørelse. Bøye hævder dog af gode grunde ikke, at den modsætning, hun finder i Beowulf-kvadet mellem hal og hav, skulle være pointeret noget sted hos Grundtvig. Tolkningen er hendes tese eller konstruktion, og hun er endda både i en »Ekskurs« (s. 125) og en note (13) nødsaget til at indrømme, at hallen hos angelsakserne ikke altid er det menneskelige fællesskab, men undertiden et babelstårn, samt at paradis hos angelsakserne også kan skildres ved naturbilleder.

Merete Bøye illustrerer kun Grundtvigs brug af ordet og begrebet Hal med ét eneste eksempel (s. 123-124), slutstrofen i en bearbejdelse fra 1836 af Kingos salme »Hvor deilig skal Guds Kirke staae« (1699). Hvorfor lige denne salmeredaktion skal fremdrages, begrundes ikke. Bøye gør opmærksom på, at Grundtvig ændrer forlæggets »Himmerig « til »din Hal saa skiøn«. Da begge strofer aftrykkes, er det let at konstatere, at Grundtvig i billedet tilstræber det konkrete og i stilen det let arkaiserende. Kingos typiske »jeg « håber, at Gud vil danne hans hjerte, så det kan dyrke Gud; Grundtvigs kollektive »vi« ønsker sig hjerter, der slår højt for himlen. Grundtvig tydeligg ør Kingos antitese mellem »i Mig « og »Dig (...) i Himmerig« til en allittererende modsætning mellem »lavt (...) hos os i Løn« - hvad Grundtvig andetsteds har kaldt »lave Hytter « - og »hisset i din Hal«. Modellen angiver altså forskellen mellem her og hisset. Merete Bøyes vurdering, at Grundtvig har flyttet Himmeriget ind i hallen, er besynderlig, for ligger den hal, som bliver himlens ydre fremtoning, ikke netop i himlen? Nogle allitterationer, Grundtvig har tilsat, peger for Bøye især i retning af en angelsaksisk forestillingsverden. Der er dog intet, der ikke lige så godt eller bedre kan forklares på oldnordisk grund: hallen i himlen er en variant af Valhal, hvor døden ikke eksisterer, mens Bedas og Beowulfkvadets hal netop er en jordisk bygning, truet og hærget udefra af henholdsvis vinterstorme og dødbringende monstre. Parallellen duer kun, hvis man antager, at Grundtvig oph øjer angelsaksernes verdslige hal til billede på Himmerig, med tryghed som fællesnævneren. Det falder noget kunstigt og kan ikke belægges i teksten eller dens sammenhæng. 
Generelt må det bemærkes, at Grundtvig næppe tolker ordet og begrebet $\mathrm{Hal}$ på angelsaksisk eller Andreas Haardersk vis. Bedas kønne parabel har han faktisk gengivet i Haandbog $i$ Verdens-Historien, II, 1836 (US VII, 1908, s. 13), men køligt og henkastet, vel fordi den ytres af en hedning og ikke dækker Grundtvigs kristelige anskuelse af det jordiske liv.

Det kan være oplysende at se nærmere på lidt ord- og begrebshistorie - før Grundtvig og hos Grundtvig. Bøye mener, at i dele af angelsaksisk poesi og hos Grundtvig kan $\mathrm{Hal}$ fungere som en eskatologisk størrelse afbildende »idealtilstanden, (...) Paradiset eller livet « (s. 124). Det er da vist i øvrigt tre ikke umiddelbart sammenfaldende betydninger.

Ordet $\mathrm{Hal}$ er på Grundtvigs tid ikke gammelt og kendt i almindelig dansk sprogbrug. Håndbøgerne - Kalkars gammeldanske Ordbog, $\mathrm{Hol}$ bergordbog, Ordbog over det danske Sprog og Peter Skautrups Det danske Sprogs Historie, suppleret med Paul V. Rubows stilhistoriske monografi Saga og Pastiche, 1923 - fortæller sammenlagt, at ordet tidligst dukker op på dansk hos historikerne som andetled i egennavnet Valhal(la). Holberg anfører således (1729 og 1732) som forklaring på navnet, at -hal er »et prægtigt huus eller pallatz«, en »Bolig eller en stor Sall, som det endnu heder hos de Engelænder, hvilke have conserveret mange af de Nordiske Ord «. Ordet forekommer ham tydeligt nok temmelig fremmed. I sin oldnordiske digtning i 1770'erne bruger Ewald betegnelserne Slot eller Gaard, om et interiør oftest Sal. I hans utrykte fragment af fortællingen »Frode «(Fredegod) fra ca. 1773 beskrives dog »en enlig Halle« fra hedenskabets tid ved bredden af Isefjord nær den gamle kongeby Lejre - den er bygget af jætter, med uhyre kampesten til vægge og hele træer tvært henover til tag, tilmed udefra beskygget af fem brede egetræer. For Ewald er $\mathrm{Hal}$ åbenbart noget ældgammelt, jætteagtigt og eksotisk skrækindjagende. Tidens forestilling om haller er måske synlig på den lidt yngre dekorationstegning af Thomas Bruun til Det Kongelige Teaters opførelse i 1785 af Birgitte Boyes drama Gorm den Gamle. Her ses Herthes tempel som et interiør med råt tilhugne granitpiller i stedet for antikkens søjler og en skummel jordhule som centrum i bagtæppet.

Men i hvert fald på tryk (hos Birgitte Boye, Jens Baggesen m.fl.) foretrækkes gang på gang udtrykket $\mathrm{Sal}$. Selv hos romantikerne kommer Hal (ud over navnet »Valhal«) overraskende sent i brug - uvist hvorfor tilsyneladende ikke før 1809. Grundtvig præsenterer det i Saga om Nor 
fra januar 1809 og derpå i Optrin af Kampelivets Undergang $i$ Nord, 1809-1811, og andre følgende tekster. Oehlenschläger introducerer det i sørgespillet Palnatoke fra marts 1809 i sin indledende regiangivelse: »Kongens $\mathrm{Hal}$ « og fortsætter denne brug af ordet i sin senere dramatik. Før studiet af angelsaksisk fra sommeren 1815 anvender Grundtvig $\mathrm{Hal}$ i to beslægtede betydninger: nutidigt arkaiserende om Frederik VI's slot på hans første fødselsdag som konge og om hertugen af Augustenborgs residens, historisk om Vølsungernes, Gorm den Gamles og Olav den Helliges kongesæder. I det i 1814 skrevne historiske digt »Et Blad af Jyllands Rimkrønike«, trykt i december 1815 i samlingen Heimdall, beklager Grundtvig i strofe 12, at Jylland mangler en anselig kongebolig, idet der - efter branden 1808 - kun er sod og grus, hvor »Stod fordum Hallen Koldinghuus / Med Taarn og Høielofte« (US III, 1905, s. 198). Ordet er en sproglig variation af betegnelserne »Konge-Slot, Kiæmpesale« tidligere i samme strofe.

I Grundtvigs behandling af det angelsaksiske synes $\mathrm{Hal}$ ligeledes først og fremmest at fungere som sproglig variant. Da Grundtvig i aprilheftet af Danne-Virke II, 1817, leverer et referat af Beowulf-kvadets handling, skriver han kun ét sted »Hrodgars Hald « (s. 256) om den berømte Hjorte-hal (Heorot), mens han ellers bruger ord som »Borg, Borge-Stuen, Salen «; artiklens andet Hal-eksempel, »en vandtæt Hald « (s. 243), går på Grændels moders unders $\varnothing$ iske tilholdssted, som betyder alt andet end det, Heorot står for (i 1820-oversættelsen rettes det s. 138 til »et vandtæt Rum«). I oversættelsesprøverne i Danne-Virke IV, vist udsendt i november 1817, bruges ordene »Borg, Hjerte-Borg, Hallen, Konge-Hald, Sal « dels tilfældigt varierende, dels bestemt af rytme og enderim. Noget tilsvarende gælder Grundtvigs komplette fordanskning af kvadet i 1820: der registreres »Hallen, høien Hald, Kæmpe-Hald, Konge-Hald «, men hyppigere »Borgen, Hjorte-Borgen, Skjoldung-Borg, Stuen, Kæmpe-Stue, Borge-Stue, Konge-Huus, Kongens Gaard, Salen, Konge-Sal, Herre-Sale, Skjoldunge-Slot « samt det vagere »Under HøieLofte «. Bogens »Navne-Tal « (register) har under opslaget »Hjorte « kun forklaringen »Borgen « (s. 318), og i de 20 sanges enkeltoverskrifter, hvor Grundtvig er ubundet af rim og versemål, foretrækker han »Borg «. Sammenlagt bruger han altså hellere ordforrådet fra det 16.-17. århundredes nedtegning af folkeviserne end en efterligning af angelsaksisk diktion.

Endnu mere påfaldende er det, at Grundtvig i Nordens Mythologi, 1832, efter tre somres intensive angelsaksiske studier i England kan 
genfortælle Beowulf-kvadets handling uden at bruge $\mathrm{Hal}$ om Rodgars hus - det er »et i Norden mageløst Slot, Hjortholm (!), Borgen, SteenStuen«, mens Grændels mødrene hjem nu hedder »en Glarhald « (US V, 1907, s. 737-740). Stikprøverne kan slutte i Grundtvigs skolebog Graesk og Nordisk Mythologi for Ungdommen, 1847, hvor det hedder »Borg, Borgen, Hall«, mens hekseboligen i sumpen er en »Glarhall« (s. 252253).

Ingen af disse mange steder forbinder Grundtvig andet med $\mathrm{Hal}$ end en given ganske konkret lokalitet (eller flere) i den berettede handling. Hvis Grundtvig skulle mene noget præcist fra angelsaksisk tankeverden med begrebet og ordet, synes han i det mindste ikke selv at være klar over det. Det nærmeste, vi indtil nu er kommet en Grundtvig-ordbog, stikordregistret i Helge Toldbergs disputats Grundtvigs symbolverden, 1950, har ingen opslag på Hal.

Hvad angår anden del af Merete B $\varnothing y e s$ antitetiske eskatologi - Hav fortsætter og dokumenterer hendes argumentation Bradleys fornemmelse af åndeligt slægtskab mellem Grundtvigs Sidste Digt og angelsakserne. Ligesom $\mathrm{Hal}$ findes $\mathrm{Hav}$ i Grundtvigs skrifter før hans bekendtskab med angelsaksisk litteratur; Helge Toldberg har en snes henvisninger til ordet (som dog ikke indgår i Bøyes litteraturhenvisninger). Ny er hendes fremdragelse og sammenstilling af Grundtvigs fire prædikener over Mattæus 8.23-27 for årene 1835, 1838, 1840 og 1841. Mon ikke Grundtvigs talrige, forholdsvis ukendte prædikener byder på et meget bedre materiale til en unders $\emptyset$ gelse af hans allegoriske billeder end hans poesi? På prædikestolen kan han ikke gå ud fra, at tilhørerne er indstillet på at kæmpe sig frem til en mening - her er det ham, som opruller en sammenligning og med det samme forklarer den. Sært er det dog, at B $\varnothing$ ye vil identificere de i 1835-prædikenen omtalte "Hedninger «, der ligner menneskelivet ved en fart på havet, med angelsakserne (s. 129), da al overleveret angelsaksisk poesi er skrevet af kristne og har klar kristelig tendens.

Endelig kommer Merete Bøye til Sidste Digt, som hun hævder er gennemsyret af et kristent tilværelsessyn (s. 131). Herom vil ingen, slet ikke en Grundtvig-forsker, tvivle. Men når man, som jeg i forbigående gjorde i 1983 i Grundtvig og grundtvigianismen $i$ nyt lys (s. 41), unders $\emptyset$ ger »romantiske træk i billedsprog og billedkombinationer «, har man i kraft af konkrete ord som »Faldereb, Magneten, Uglesangen, Færge-Stavnen, -Havnen, Kompas, Time-Glas « et mini-epos, der ikke står i evangelierne. I »Evighedens Port, Jesus-Christus-Navnet, Him- 
merig, Guds-Bordet « vender Grundtvig tilbage til almene kristelige forestillinger, med et fald i digterisk intensitet, som ikke svarer til slutlinjens glæde over indbydelsen til den himmelske nadver. Bøyes sammenligning mellem den havtrætte angelsaksiske Seafarer, der ikke er gammel, men erfaren, og Grundtvigs tilstrækkeligt gamle »jeg « $\mathrm{i}$ Sidste Digt er dels temmelig almen, dels uholdbar, da hun selv må medgive, at angelsakserens sule-, spove- og mågeskrig ikke er Grundtvigs uglesang (eller omvendt), og at søfarerens længsel tilbage til forrige havnebys paradis ikke er det samme som Grundtvigs beklagelse af afstanden til paradishaven på jorden. Ikke desto mindre konkluderer Bøye, at de opregnede lighedstræk tyder på, at Grundtvig har haft »The Seafarer « i tankerne, da han skrev Sidste Digt (s. 136).

Tesen om, at en vidt og bredt belæst og mageløs produktiv poet absolut skal have ét bestemt forbillede for et afskedsdigt med verden, passer ikke godt til Grundtvigs lange praksis. Lige siden gratulationsdigtet til faderens præstejubilæum den 5. december 1810 har Grundtvig udviklet og forfinet en poetisk teknik, som går ud på at sige det egentlig uudsigelige ved at kombinere og udveksle billeder fra helt forskellige perioder, litteraturer og religioner. En tolkning af Sidste Digt kan ikke yde teksten retfærdighed ved et enten-eller, men ved et både-og. Styrken i den del af Grundtvigs lyrik, hvor han først og fremmest nedtegner de inspirerede syner i størst mulig sandhed, ligger netop i det mangetydige. Som han selv har sagt det fyrre år tidligere i Nordens Mythologi, 1832, stillet over for spørgsmålet om, hvorvidt sagnet om Beowulfs skjulte skat kan identificeres med grækernes sagn om det guld, Kronos nedgravede i Norden (US V, 1907, s. 742): »begge Dele kan speile sig deri, det seer jeg nok, og det var formodenlig Hoved-Sagen i Drape-Smedens Øine, siden det er saa i alle Skjaldes, der netop blive sande Spaamænd, fordi de ikke drive Sandsiger-Handværket, men har kun deres store Fornøielse af at see Tider og Begivenheder speile sig i hinanden, og lade, naar de rime herom, hver nyde som han nemmer!« 